\title{
No-till strip row farming using yearly maize-soybean rotation increases yield of maize by $75 \%$
}

\author{
Rafiq Islam • Dean C. Glenney • George Lazarovits
}

Accepted: 20 January 2015 / Published online: 27 February 2015

(C) INRA and Springer-Verlag France 2015

\begin{abstract}
Development of agronomic practices that maximize the use of natural resources to improve soil health and crop productivity is critical for long-term sustainability of agricultural technologies. In Ontario, Canada, the most conventional maize production practice follows a 3 -year rotation with soybeans and ploughing of the land before planting and after harvesting. This technology yields $8-10 \mathrm{t} \mathrm{ha}^{-1}$ of maize. We became aware of a long-term no-till strip row farming system developed by an Ontario grower where maize yields are double that of the average for the province. This study set out to identify what factors contribute to such a massive yield increase and the basis for this superior method of maize production. In a 2-year field study, we compared a variety of biotic and abiotic factors associated with yields at this highly productive site with those of two average yielding sites. The notill strip row farming system grew maize and soybeans in alternate strips rotated yearly and had higher plant populations, better root architecture, higher plant biomass, and $75 \%$ greater $\left(18.35 \mathrm{t} \mathrm{ha}^{-1}\right)$ grain yield compared to a nearby farm that used conventional production practices. About $21 \%$ of the yield increase resulted from early planting, greater number of seeds planted, and healthier ears/seeds. The remaining $54 \%$ increase was linked to larger ears, which we tentatively attribute to beneficial effects conferred by the microorganisms that develop in this unique agro-ecosystem. The average net return at the no-till site was estimated to be $\mathrm{CDN}$ (Canadian) $\$ 2000 \mathrm{ha}^{-1}$, which was $400 \%$ higher than the net returns of the conventional sites. The study concludes that no-till management where soil remains undisturbed when combined with yearly rotations of an appropriate legume crop, growing crops exactly on the same cropping rows every year, and
\end{abstract}

R. Islam $(\bowtie) \cdot$ D. C. Glenney $\cdot$ G. Lazarovits

A\&L Biologicals, Agroecological Research Services Centre, 2136

Jetstream Rd, London, ON N5V 3P5, Canada

e-mail: rafiq@alcanada.com optimization of plant density creates a sustainable technology for maximizing maize yields.

Keywords Long-term no-till · Strip row farming · Conventional production practice - Yearly maize-soybean rotation - Optimum plant density $\cdot$ Maize yield improvement $\cdot$ Increased net return

\section{Introduction}

Technological innovations that increase crop yield, reduce farmers' cost, improve soil health, and protect the environment are necessary for the next generation of agricultural production systems (Hobbs et al. 2008). Agricultural practices that rely on chemicals and tillage are not considered to have much potential for contributing to future yield increases (Edgerton 2009). Many components of such practices have become costly to growers while degrading soil physical structure and negatively impacting the environment (Savci 2012).

Cropping practices such as no-tillage systems combined with crop rotation using appropriate plant species and retention of crop residues on the soil are known to minimize many of the adverse effects caused by current crop production practices (Hobbs et al. 2008). Advantages of the no-till cultivation systems include cost, protection of soil integrity, reduction in erosion, conservation of soil moisture, reduced soil temperatures during summer, and fewer emissions of greenhouse gases (Hobbs et al. 2008; Piva et al. 2012). No-till systems also improve physical, chemical, and biological properties of soil (Martinez et al. 2013), including the evolution or maintenance of beneficial microbial communities that arise from minimal soil disturbance and appropriate crop rotations (Peters et al. 2003).

In Ontario, Canada, maize is grown under rain-fed conditions, and conventional maize production relies on ploughing 
the land in the fall followed by a second tillage in the spring to incorporate the crop residue. Seeds are most commonly planted in rows with 50-75 cm spacing, and crop sequences follow a 3-year rotation of cereals, forages, or soybeans (Glycine $\max$ L. Merr). No-tillage farming usually involves minimal soil opening in a narrow band, followed by seeding into the bands using planter-mounted coulters and/or residue clearing devices. The crop rotations are similar for both methods and they generally obtain similar yields averaging $9.2 \mathrm{t} \mathrm{ha}^{-1}$ (153.5 bu ac${ }^{-1}$ ) (Bagg et al. 2009; Anonymous 2008-2012). An Ontario grower, Mr. Dean C. Glenney, developed a no-till strip row farming system, which he termed Fence Row Farming (http://www.ontariograinfarmer.ca/ MAGAZINE. aspx?aid=572). While Mr. Glenney was working at the family farm at a young age, he noticed that the plants growing along the undisturbed fence rows had better growth than the crops in rest of the ploughed field. This observation encouraged him to gradually convert his conventional maize field to no-till strip row farming. Maize yields began to increase in his field after 5 to 6 years of initiating the practice and have kept increasing as the system continues to be refined (Rhoton 2000; Martinez et al. 2013). He plants seeds exactly on the same cropping rows every year by passing through the mulch using a planter he designed. The planter wheels never roll over the cropping rows; thus, the rows have remained undisturbed since this practice began. Maize and soybeans are grown in strips and alternate yearly (Fig. 1). Now, after 15 years of this practice, average yields are $18.82 \mathrm{tha}^{-1}\left(300 \mathrm{bu} \mathrm{ac}^{-1}\right)$, more than double the average of 9 . $2 \mathrm{t} \mathrm{ha}^{-1}$ found in Ontario (Anonymous 2008-2012). Soybean yields average $4.0 \mathrm{tha}^{-1}\left(60 \mathrm{bu} \mathrm{ac}^{-1}\right)$, slightly higher than the Ontario average. It is possible that allelopathic effects associated with maize-soybean rotations may limit the yield increases expected with soybeans at the no-till site (Mamolos and Kalburtji 2001). An understanding of what changes brought about the increased maize yield is of great interest to both the grower and the industry. The aim of our study was to identify key biological and non-biological factors involved in the yield increases by comparing factors to those found at a nearby farm where conventional production practices were used.

\section{Materials and methods}

\subsection{Establishment of field experiments}

This study was conducted at two farmers' fields located in Dunnville, Ontario, Canada, during 2012 and 2013 crop seasons. The no-till strip row maize farm is a 75 ha area of land at $42^{\circ} 56^{\prime} 06.28^{\prime \prime} \mathrm{N}$ and $79^{\circ} 41^{\prime} 00.92^{\prime \prime} \mathrm{W}$. The size of each strip is $4 \mathrm{~m}$ wide and $80 \mathrm{~m}$ long. Two nearby conventional production sites owned by the same farmer are located at $42^{\circ} 56^{\prime}$ $45.11^{\prime \prime} \mathrm{N}$ and $79^{\circ} 33^{\prime} 02.06^{\prime \prime} \mathrm{W}$. The strip farm is $5 \mathrm{~km}$ from the conventional maize fields. Soils of the experimental sites are characterized by BRR5 and TLD2, Berrien and Toledo. The parent material for the experimental site is $15-40 \mathrm{~cm}$ sandy texture over lacustrine silty clay and $40-100 \mathrm{~cm}$ sandy sediments over lacustrine clay and silty clay. The two conventional production sites, termed conventional-1 site (in 2012) and conventional-2 site (in 2013), are both about 50 ha each. In 2012, the no-till strip row site was designated as no-till-1 site and was compared with the conventional-1 site. In 2013, as regular practice, the maize and soybean strips were alternated with each other and the plot was designated as no-till-2 site and compared with conventional-2 site. Land preparation, planting, and crop management were done by the farmers without changing their normal practices, except that we

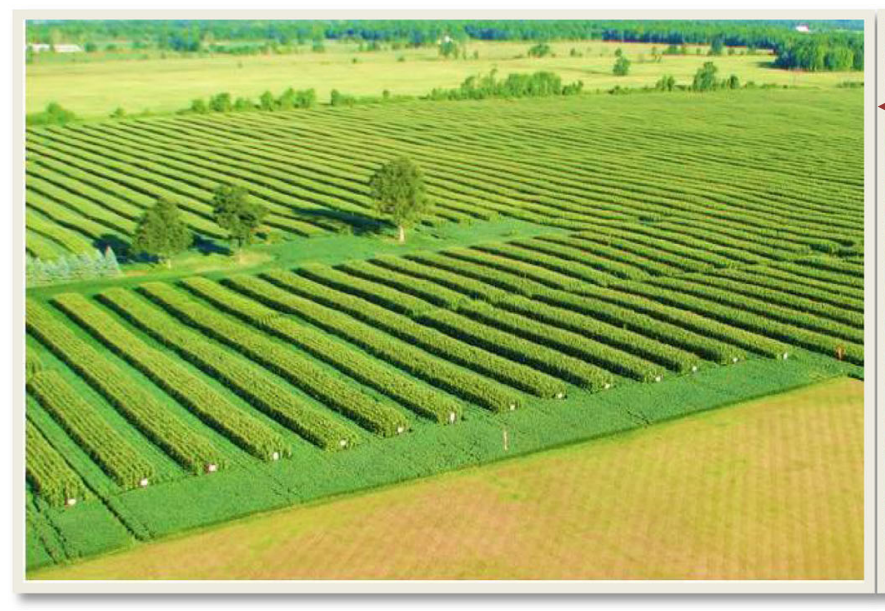

Fig. 1 Long-term no-till maize-soybean (soya) strip row farming practice located in Dunnville, Ontario, Canada. Left, alternate maize and soybean strips. Right, experimental site in June 2013 demonstrates that crops are grown in twin rows and retain crop residues on the soil surface.

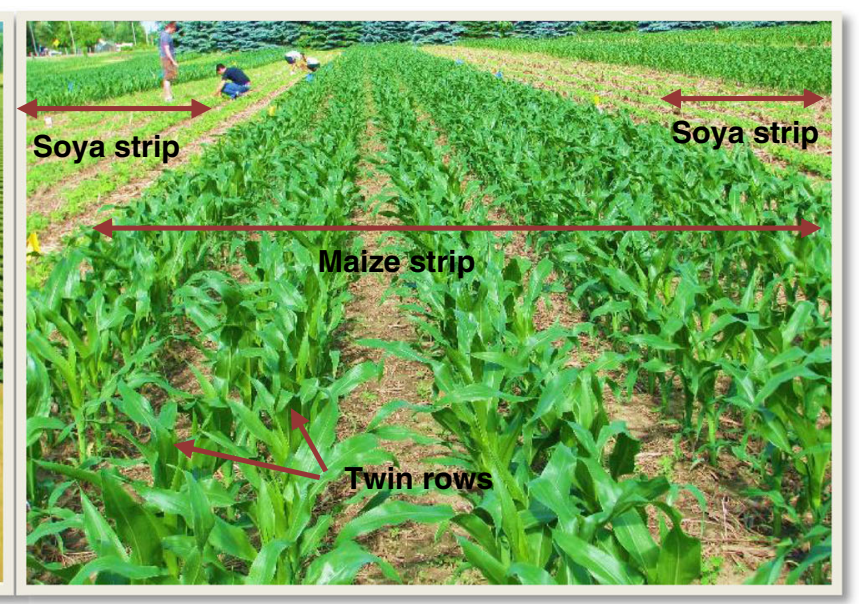

The maize and soybean strips shown here were planted with alternate crop in 2012. In 2013, planting was done exactly on the previous cropping rows 
requested that both farmers plant the identical maize hybrid. We randomly chose four replicate plots $(10 \mathrm{~m} \times 4 \mathrm{~m}$ each $)$ in each field and designated these as the experimental plots. The history of the no-till farm and the cultural practices between the experimental sites were recorded.

\subsection{Soil properties, moisture content, and plant population}

At 30, 60, and 90 days (d) after seed sowing, 20 whole plants were randomly selected from each of the four replicate plots and removed using a clean shovel. The plants were brought back to the laboratory for further analyses. The soil attached to the roots (approximately $10-30 \mathrm{~cm}$ depth soil) was shaken off from all harvested plants and used for analysis of soil texture, soil organic matter content, $\mathrm{pH}$, and nutrients. Two hundred grams of each soil sample was oven-dried at $80^{\circ} \mathrm{C}$ for $24 \mathrm{~h}$ to determine the moisture content. The plant populations of $4 \mathrm{~m} \times 2 \mathrm{~m}$ areas plot $^{-1}$ were determined at $30 \mathrm{~d}$. The collected plants and soils were used for analyses as described in the following sections.

\subsection{Nutritional status of root zone soil and plant tissues}

Chemical analyses of soils included available $\mathrm{NO}_{3}-\mathrm{N}$, essential micro-/macro-nutrients (in $\mu \mathrm{g} \mathrm{ml}^{-1}$ ), base $(\mathrm{K}, \mathrm{Ca}, \mathrm{Mg}$ ) saturation (\%), cation exchange capacity (in meq $100 \mathrm{~g}^{-1}$ ), and $\mathrm{K} / \mathrm{Mg}$ ratio as described above (Jones 1999; Rice et al. 2012). Individual plant roots, stems, leaves, and cobs (if any) were separated. Stem and leaf tissues of the 20 plants at each growth stage were also analyzed for micro-/macro-nutrients, and the values were compared to expected values published for soil and maize plants by Bagg et al. (2009), Anonymous (2001), Mills and Jones (1997), and personal communication to Mr. Greg Patterson, Certified Agronomist with A\&L Canada Laboratories Inc.

\subsection{Leaf chlorophyll content, shoot height, and dry plant biomass}

Chlorophyll content of three young leaves from each of the 20 maize plants at three growth stages was measured using a SPAD-502 meter (Konica Minolta, Osaka, Japan) in the field sites. Shoot heights were measured after the plants were brought to the laboratory. Roots were cleaned by washing with running tap water. The roots, stems, and leaves of individual plants were chopped into small pieces and dried for $24 \mathrm{~h}$ at $80^{\circ} \mathrm{C}$, and their dry biomasses were measured.

\subsection{Root and cob diseases and yield losses}

Before taking the dry weight, the number of nodal roots per plant and number of plants which had roots that reached/ penetrated the plough pan layer $(>35 \mathrm{~cm})$ were determined at $90 \mathrm{~d}$. Root health of plants at the three growth stages was determined by visual examination under a binocular microscope, and the incidence of root damage was recorded. Five months after sowing, 400 maize plants were randomly harvested from each site for determination of yield and the impact of disease on grain quality. The incidence and severity of diseased ears were grouped into the following categories; healthy (0-4.9\% infection at the cob tip), mild (5-9.9\%), moderate (10-19.9\%), and severe (20-30\%). Diseased grains from each of 400 ears from each site were counted and converted to grain loss from each ear as a percentage based on the total seeds counted, and the values were averaged to determine yield losses.

\subsection{Grain yields, nutritional values of kernels, cost of crop} production, and net return

The length and diameter of 100 randomly chosen ears from each field were measured. The total number of kernels per ear was determined, and 50 kernels from each plot were randomly chosen and weighed. The weights per plot of the total harvested grain were determined based on $15.5 \%$ moisture content. The nutritional status of harvested kernels from no-till and conventional sites was also determined (Jones 1999; Horwitz 2003). Total cost of production included input, labor, machinery, crop insurance, handling/processing grains, and marketing. The gross return was calculated from the yield $(\mathrm{kg})$ per hectare multiplied by the price per kilogram. Net income was determined by subtracting total cost from gross return.

\subsection{Statistical analysis}

The data were analyzed using SigmaPlot 12.0 software (Systat Software Inc., San Jose, CA, USA). The results were averages of 20 replications, stated as mean \pm standard error. Differences between means were considered significant at probability $(p)$ value lower than $5 \%$ according to Tukey's HSD test.

\section{Results and discussion}

3.1 Differences of soil properties, soil moisture, and cultural practices between no-till and conventional sites

\subsubsection{Soil properties and moisture levels at different plant growth stages}

The soils of no-till and conventional- 1 and -2 sites were identified to be sandy loam, sandy clay loam, and loamy sand, respectively (Table 1). The soils belonged to the coarse texture class and were considered to have good internal drainage capacity. The root zone soil $(10-30 \mathrm{~cm}$ depth) from no-till site contained $3.0 \%$ organic matter, the average found in most 
arable soils in this region. Soil $\mathrm{pH}$ of plots at the no-till site was 7.0, which is suitable for maize growth. The conventional- $1 / 2$ site soils had 5.3/7.2 \% organic matter and $\mathrm{pH}$ of 7.5/ 7.4 , respectively. The higher organic matter in the root zone soils of conventional sites could benefit the crops, but the $\mathrm{pH}$ values were slightly above the optimum range for maize, which might negatively impact yields at these sites. Some possible reasons for higher organic matter at the conventional sites could be the differences of soil type and tillage practice compared to the no-till site. A number of studies revealed that the deposition of organic matter in the top soil $(0-10 \mathrm{~cm}$ depth) was higher in long-term no-till soil compared to conventional fields. In contrast, organic matter content at the depth of 12-30 cm appeared to be higher in tilled soil than that in no-tilled soil (Deen and Kataki 2003; Franzluebbers and Stuedemann 2014; Liu et al. 2014). We were unable to find any published relationship between soil organic matter and crop productivity and thus did not assign any role for this factor to yield impacts at any site used. Moisture levels in the root zone soils were determined to be very similar at no-till-1/ conventional-1 and no-till-2/conventional-2 sites, suggesting that yield variations were not related to moisture deficiency or waterlogging conditions.

\subsubsection{Cultural practices}

A variety of factors were found to be similar and dissimilar in the cultural practices used at the no-till and conventional sites over the 2 years of this study (Table 1). Similarities included the following: growing the identical maize hybrid (P0216 AM-R), east to west crop row direction, and no foliar pesticide application. The major differences between the two farming systems were as follows: At the no-till site, the land was not ploughed, maize and soybean strips (each $4 \mathrm{~m}$ wide) were alternated, crops were grown exactly on the previously grown rows, and crop residues were retained on the soil surface. In contrast, soil at the conventional sites was ploughed before sowing, crop residues were incorporated into the soil, and 2 years of maize production was followed by 1 year of soybeans. Seeding at the no-till site was done on May 5th, the recommend date (before or on May 7th) for this climatic zone, whereas sowing occurred 1 week later than the recommend date at the conventional sites.. According to Bagg et al. (2009), one can expect a $1 \%$ yield reduction per day of late planting; thus, we assume that this led to a $7 \%$ yield loss at this site. Maize at the no-till site was grown in $20 \mathrm{~cm}$ twin rows and the seeds were placed $25 \mathrm{~cm}$ apart, with a $55 \mathrm{~cm}$ gap between the twin rows (Fig. 1). At the conventional sites, the row spacing was $75 \mathrm{~cm}$ and seeds were placed $15 \mathrm{~cm}$ apart. As a result, the numbers of standing maize plants at the no-till-1/2 sites were 79,500/80,400 $\mathrm{ha}^{-1}$, compared to the conventional$1 / 2$ sites where $72,300 / 72,200 \mathrm{ha}^{-1}$ plants were counted. The extra 7,000-8,000 plants are expected to increase the yield difference about $10.5 \%$. The row spacing may also contribute to higher yields. Gozubenli et al. (2004) found that maize when grown in twin rows often yielded significantly better than those in single-row systems when there were 90,000 plants ha ${ }^{-1}$. The fertilizer rates at the no-till and conventional-1/2 sites differed only slightly (Table 1 ), but banding fertilizer has been shown to benefit yields. However, we are unable to assign a yield factor to fertilizer placement.

3.2 Analysis of micro- and macro-nutrients in soils and maize stem/leaves from no-till and conventional sites

\subsubsection{Plant available mineral nutrients in root zone soil}

At all sites, $\mathrm{NO}_{3}-\mathrm{N}$ in soils from the root zone at $30 \mathrm{~d}$ was found to be in the optimum range $\left(10-25 \mu \mathrm{g} \mathrm{ml}^{-1}\right.$ ) (Table 2A). $\mathrm{NO}_{3}-\mathrm{N}$ levels in other sites decreased as the season

Table 1 Comparisons of the soil properties and maize management practices between no-till and conventional fields

\begin{tabular}{|c|c|c|c|c|c|c|c|c|c|c|}
\hline \multirow[t]{2}{*}{ Crop field } & \multirow[t]{2}{*}{ Soil texture } & \multirow[t]{2}{*}{$\operatorname{SOM}(\%)$} & \multirow[t]{2}{*}{$\mathrm{pH}$} & \multirow[t]{2}{*}{ Till/no-till } & \multirow[t]{2}{*}{ Crop rotation } & \multirow[t]{2}{*}{$\begin{array}{l}\text { Plants } \\
\text { ha }^{-1}\end{array}$} & \multirow[t]{2}{*}{$\begin{array}{l}\text { Row/plant } \\
\text { spacing }(\mathrm{cm})\end{array}$} & \multicolumn{3}{|c|}{$\begin{array}{l}\text { Fertilizer } \\
\left(\mathrm{kg} \mathrm{ha}^{-1}\right)\end{array}$} \\
\hline & & & & & & & & Urea & $\mathrm{P}_{2} \mathrm{O}_{5}$ & $\mathrm{~K}_{2} \mathrm{O}$ \\
\hline No-till-1 & Sandy loam & 3.0 & 7.0 & Not tilled & Maize-Soybean-maize & 79,500 & $\begin{array}{l}\text { TR } 20 \\
\text { BTR } 55 \\
\text { BP } 25\end{array}$ & 230 & 60 & 28 \\
\hline Conventional-1 & Sandy clay loam & 5.3 & 7.5 & Tilled & Maize-maize-Soybean-maize & 72,300 & $\begin{array}{l}\text { BR } 75 \\
\text { BP } 15\end{array}$ & 250 & 28 & 67 \\
\hline No-till-2 & Sandy loam & 3.0 & 7.0 & Not tilled & Same as no-till-1 & 80,400 & Same as no-till-1 & 230 & 60 & 28 \\
\hline Conventional-2 & Loamy sand & 7.2 & 7.4 & Tilled & Same as conventional-1 & 72,200 & Same as conventional-1 & 200 & 30 & 56 \\
\hline
\end{tabular}

The no-till experimental site was designated as no-till-1 and no-till-2 in the 2012 and 2013 crop seasons, respectively. Conventional- 1 and conventional-2 represent the conventional experimental sites in the years 2012 and 2013, respectively. Pioneer Hi-Bred P0216 AM-R* maize variety was grown in all experimental sites. *AM-R genetically modified Pioneer Hi-Bred maize hybrid resistant to rootworm, herbicide, and European stem borer'

$S O M$ soil organic matter, $T R$ twin rows, $B T R$ between twin rows, $B P$ between plants 


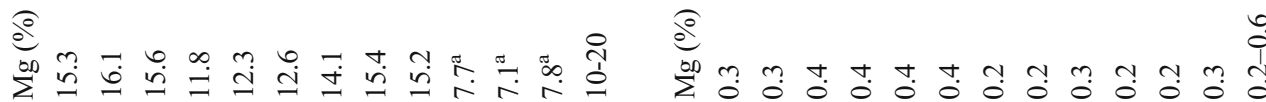

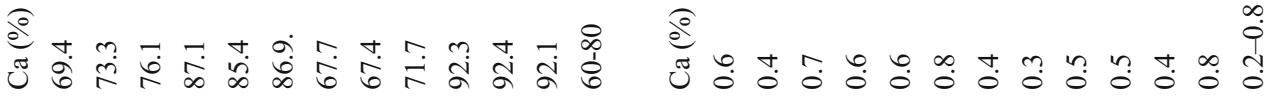

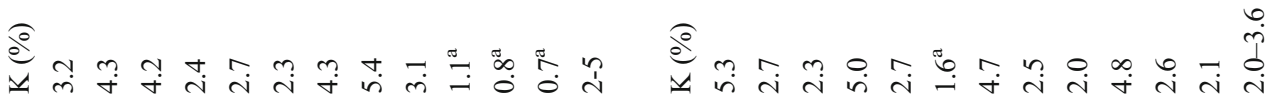

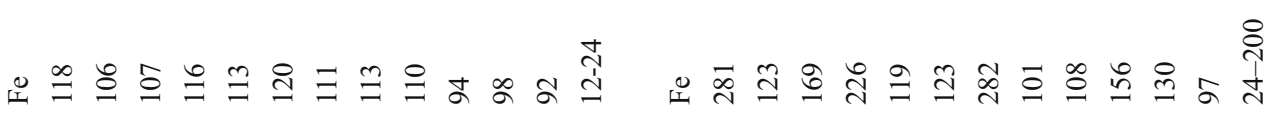

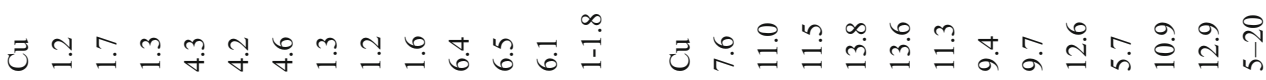

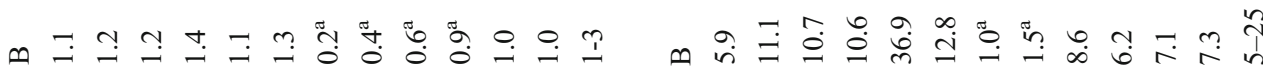

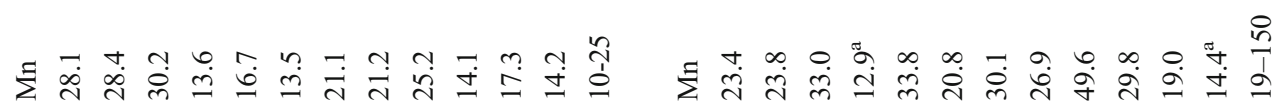

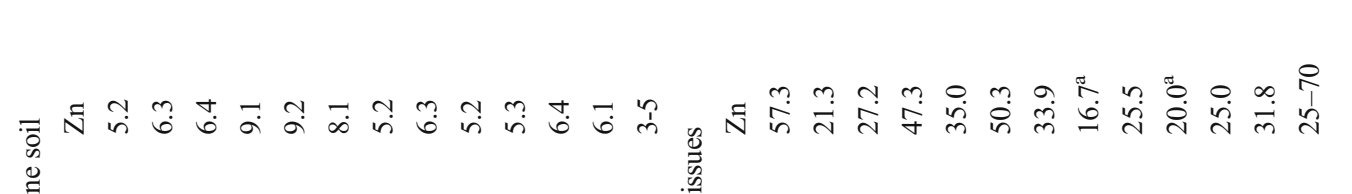

$\frac{10}{8}$

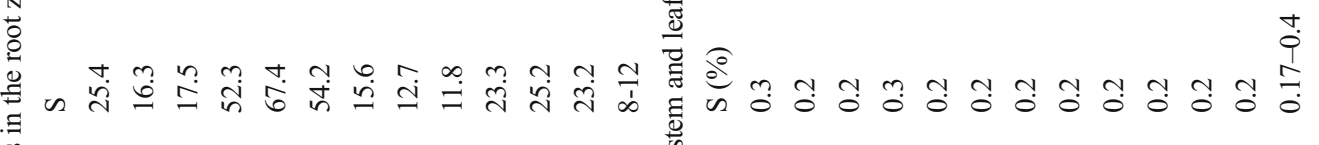

(5)

然

贾

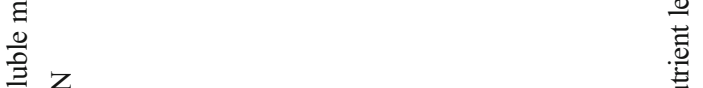

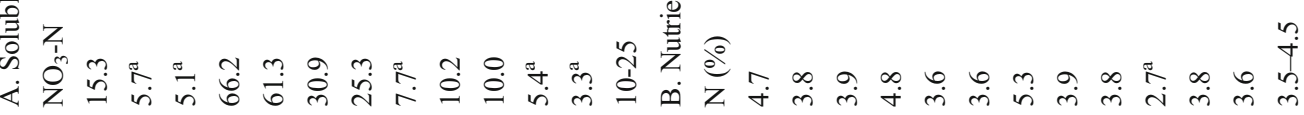

융ㅇㅇㅇㅇㅇㅇㅇㅇㅇㅇㅇㅇㅇㅇㅇㅛ

융요융유요유요 
progressed, except that no-till-2 soil at $90 \mathrm{~d}$ contained higher $\mathrm{NO}_{3}-\mathrm{N}$ compared to that at $60 \mathrm{~d}$. Insufficient $\mathrm{NO}_{3}-\mathrm{N}$ was found in no-till-1 soil at $60 \mathrm{~d}\left(5.7 \mu \mathrm{g} \mathrm{ml}^{-1}\right)$ and $90 \mathrm{~d}$

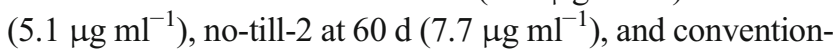

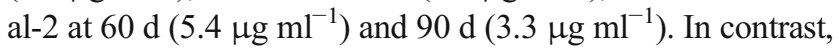
very high $\mathrm{NO}_{3}-\mathrm{N}$ was found in conventional-1 soils at all three growth stages $\left(66,61,30 \mu \mathrm{g} \mathrm{ml}^{-1}\right.$, respectively), presumably due to high organic matter content in the soil. Most mineral nutrients in no-till- $1 / 2$ sites soils were adequate or above the optimal ranges (K, 2-5\%; Ca, 60-80\%; Mg, 10-20\%; S, $12-$ $25 \mu \mathrm{g} \mathrm{ml}^{-1}$; Zn, 3-5 $\mu \mathrm{g} \mathrm{ml}^{-1}$; Mn, 10-25 $\mathrm{g} \mathrm{ml}^{-1}$; $\mathrm{Cu}, 1-$ $1.5 \mu \mathrm{g} \mathrm{ml}^{-1}$ ), except B deficiency was present in no-till-2 (optimum 1-3 $\mu \mathrm{g} \mathrm{ml}^{-1}$ ). Bicarbonate $\mathrm{P}$ and $\mathrm{Fe}$ in all soils were found to be higher than were considered to be the optimum ranges $\left(\mathrm{P}, 30-60 \mu \mathrm{g} \mathrm{ml}^{-1} ; \mathrm{Fe}, 12-24 \mu \mathrm{g} \mathrm{ml}^{-1}\right)$. Conventional1 site soil had very high $\mathrm{S}\left(52-67 \mu \mathrm{g} \mathrm{ml}^{-1}\right)$ and slightly high $\mathrm{Zn}, \mathrm{Cu}$, and $\mathrm{Ca}$, but normal ranges of $\mathrm{Mn}, \mathrm{B}, \mathrm{K}$, and $\mathrm{Mg}$. Conventional-2 site soil had high S $\left(23-25 \mu \mathrm{g} \mathrm{ml}^{-1}\right)$ and sufficient or above the normal levels of $\mathrm{Zn}, \mathrm{Mn}, \mathrm{Cu}$, and $\mathrm{Ca}$. This soil also had inadequate $\mathrm{K}(0.7-1 \%)$ and $\mathrm{Mg}(7 \%)$. The $\mathrm{K}$ and $\mathrm{Mg}$ ratio in the no-till site was $0.2-0.3$, which was either in optimal range or slightly above $(0.15-0.25)$, and the values were statistically higher compared to conventional-1/2 site soils $(0.1-0.2)$. Conversely, the cation exchange capacity of the conventional soils was remarkably higher $(17-21 \mathrm{meq}$ $100 \mathrm{~g}^{-1}$ ) than soils from the no-till site (9-10 meq $\left.100 \mathrm{~g}^{-1}\right)$. The higher organic matter in the conventional field soils is likely associated with the increased cation exchange capacity of these fields. Based on results of the chemical analysis, both no-till-1/2 and conventional-1 field crops had suffered from $\mathrm{N}$ deficiency, particularly at the later growth stages. $\mathrm{N}$ deficiency symptoms were visible in plants from both field plants. Interestingly, no-till site plants quickly recovered and vigorous growth was observed during 60-90 days after planting. This observation raised the question of whether the tremendous growth of maize is associated with certain microorganisms that have evolved in this long-term undisturbed soil. Although most soils had sufficient levels of other essential nutrients over the season, no-till-2 had inadequate B and conventional-2 had $\mathrm{K}$ and $\mathrm{Mg}$ deficiencies. This likely had some adverse effects on crop performance at these fields (Cakmak et al. 1994). Plants' nutrient acquisition is affected by agronomic practices (Malhi et al. 2006); therefore, the plant tissues from the fields were analyzed to confirm if plants had adequate nutrients for proper growth and development.

\subsubsection{Nutritional status in maize plant tissue}

Plant tissues from no-till site had optimal concentrations of $\mathrm{N}$ (3.5-4.5\%), P (0.3-0.5\%), S (0.17-0.4\%), Zn (25$\left.70 \mu \mathrm{g} \mathrm{ml}^{-1}\right), \mathrm{Mn}\left(19-150 \mu \mathrm{g} \mathrm{ml}^{-1}\right), \mathrm{Cu}\left(5-20 \mu \mathrm{g} \mathrm{m}^{-1}\right), \mathrm{Fe}$ (24-200 $\left.\mathrm{g} \mathrm{m} \mathrm{m}^{-1}\right), \mathrm{K}(2.0-3.6 \%), \mathrm{Ca}(0.2-0.8 \%)$, and $\mathrm{Mg}$ $(0.2-0.6 \%)$ (Table 2-B) (Mills and Jones 1997). Although no- till-2 site plants suffered from B deficiency at $30 \mathrm{~d}$ $\left(1.0 \mu \mathrm{g} \mathrm{ml}^{-1}\right)$ and $60 \mathrm{~d}\left(1.5 \mu \mathrm{g} \mathrm{ml}^{-1}\right)$, the expected level (5$\left.20 \mu \mathrm{g} \mathrm{ml}^{-1}\right)$ was met at $90 \mathrm{~d}\left(8.6 \mu \mathrm{g} \mathrm{ml}^{-1}\right)$. With some exceptions, plants from conventional- 1 and -2 sites had adequate nutrients at all three growth stages. Plant tissues from conventional-1 field had insufficient $\mathrm{K}(1.6 \%)$ at $90 \mathrm{~d}$, and $\mathrm{Mn}\left(13 \mu \mathrm{g} \mathrm{ml}^{-1}\right)$ at $30 \mathrm{~d}$. In early growth stages $(30 \mathrm{~d})$, conventional-2 site plant tissues were found to be deficient in $\mathrm{N}(2.7 \%)$, and $\mathrm{Zn}\left(20 \mu \mathrm{g} \mathrm{ml}^{-1}\right)$, and Mn deficiency was determined at $90 \mathrm{~d}\left(14.4 \mu \mathrm{g} \mathrm{ml}^{-1}\right)$. With the above exceptions, plant tissues from all sites had adequate levels of $\mathrm{N}$ in all growth stages, including the soils that were found to be deficient in $\mathrm{NO}_{3}-\mathrm{N}$. The chemical analyses indicate that overall, plants likely did not suffer from any prolonged periods of nutrient deficiency during the season and thus soil fertility did not likely contribute considerably to yield differences between fields. Taken together, these results imply that other factors, such as soil/endophytic microorganisms, could be involved in the vigorous plant growth and increased grain yield at no-till site (Ryan et al. 2008).

\subsection{Leaf chlorophyll content, shoot height, and total plant biomass}

The leaf chlorophyll content in all fields increased with plant development when examined at 30,60, and $90 \mathrm{~d}$. The chlorophyll levels of plants at the no-till site were 3-4 SPAD units higher than those at conventional sites at all dates samples (data not shown). Shoot heights were identical between fields at $30 \mathrm{~d}$, but by $60 \mathrm{~d}$, taller plants were found at no-till site compared to plants at the conventional site. The differences were significant at $90 \mathrm{~d}$ between no-till site crops (average of no-till-1/2 sites, $270 / 273 \mathrm{~cm})$ and conventional-1/2 sites (237/ $241 \mathrm{~cm})(p$ lower than $1 \%$ ) (Fig. 2a). Between 60 and $90 \mathrm{~d}$, the average shoot growth at no-till- $1 / 2$ sites and conventional$1 / 2$ sites were calculated to be $3.3 / 3.2$ and $2.2 / 2.2 \mathrm{~cm} \mathrm{~d}^{-1}$, respectively. Similarly, the total dry plant biomasses of notill and conventional sites at $30 \mathrm{~d}$ were similar (no-till-1/2 sites, 2.1/2.5 $\mathrm{g} \mathrm{plant}^{-1}$; conventional-1/2 sites, 2.4/2.3 g plant $^{-1}$ ) (Fig. 2b). By $60 \mathrm{~d}$, however, the plant biomass at the no-till-1/2 sites $(71.5 / 73.3 \mathrm{~g})$ was higher than that found at the conventional- $1 / 2$ sites $(66.9 / 68.4 \mathrm{~g})$. The average biomasses of no-till-1/2 plants (274.8/276.6 g plant $\left.^{-1}\right)$ at $90 \mathrm{~d}$ were also significantly higher than those at the conventional$1 / 2$ sites $\left(242.5 / 245.4\right.$ g plant $\left.^{-1}\right)$ ( $p$ lower than $\left.1 \%\right)$. The leaf chlorophyll, plant heights, and total biomasses were statistically similar between no-till-1 and no-till-2, and conventional1 and conventional-2 field crops. The leaf chlorophyll content results indicate that plants at the no-till site had generally higher photosynthetic capacity and leaf N, which likely contributed to the increased growth, biomass production, and seed yield (Gholizadeh et al. 2011). 


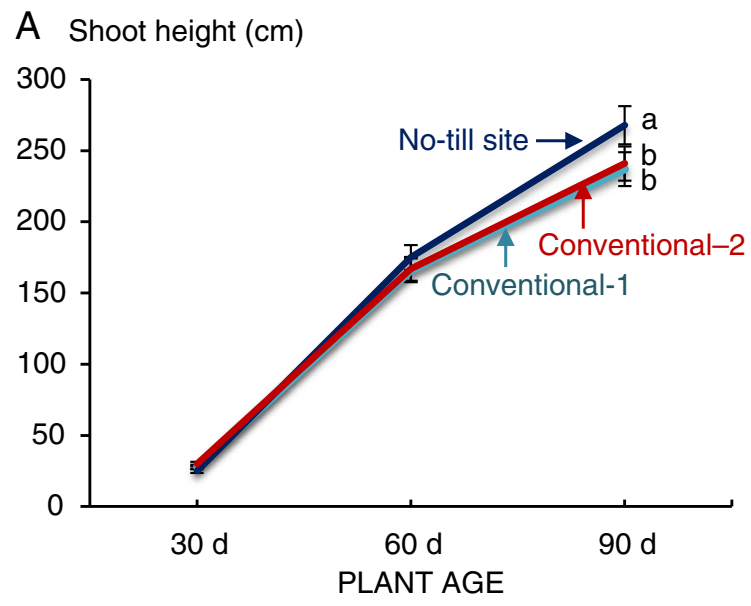

Fig. 2 Growth pattern of maize plants produced in two differentially managed production practices. a Shoot height and $\mathbf{b}$ total dry biomass of maize plants collected from long-term no-till and conventional production sites, and compared at 30,60, and $90 \mathrm{~d}$ after planting. The experiment was conducted in 2012 (no-till-1 site and conventional-1 site)

\subsection{Number of nodal roots, longer roots, and root biomass}

At $90 \mathrm{~d}$, root systems of plants from no-till sites were generally larger, thicker, longer, and more branched compared to those collected from the conventional sites. The numbers of nodal roots, considered to be crucial for supplying the majority of water and mineral nutrients to plants, was also greater at the no-till-1/2 sites: (53/54 plant $\left.^{-1}\right)$ compared to plants from the conventional-1/2 sites (48/50 plant $^{-1}$ ) (Fig. 3). More than $75 \%$ of no-till site plants had long roots (larger than $35 \mathrm{~cm}$ ) that penetrated the plough pan layer (Barraclough and Weir 1988) (Fig. 3). This implies that roots had a much easier time penetrating the porous soils at the no-till site. Conversely, significantly fewer plants from conventional- $1 / 2$ sites $(4 / 5 \%)$ had roots larger than $35 \mathrm{~cm}$ ( $p$ lower than $1 \%$ ), indicating the potentially adverse effect of tillage and compaction on soil physical properties. Although the root biomass from no-till and conventional site plants was comparable at 30 and $60 \mathrm{~d}$, by $90 \mathrm{~d}$, no-till-1/2 crops had significantly higher root biomass $\left(50.7 / 51.3 \mathrm{~g} \mathrm{plant}^{-1}\right)$ than crops at the conventional-1 (39.8 $\left.\mathrm{g} \mathrm{plant}^{-1}\right)$ and conventional-2 sites (41.0 $\left.\mathrm{g} \mathrm{plant}^{-1}\right)(p$ lower than $5 \%$ ) (Fig. 3). These results suggest that the better root growth and architecture of no-till site crops increased rate of nutrients and water uptake to the plants, which might have contributed to higher plant growth and increased grain yield.

\subsection{Insect pest/diseases and crop losses}

At 30 and $60 \mathrm{~d}$, occasional scattered brown lesions and root tip necrosis were found on roots from the no-till and conventional sites. At $90 \mathrm{~d}$, the incidence and severity of lesions were

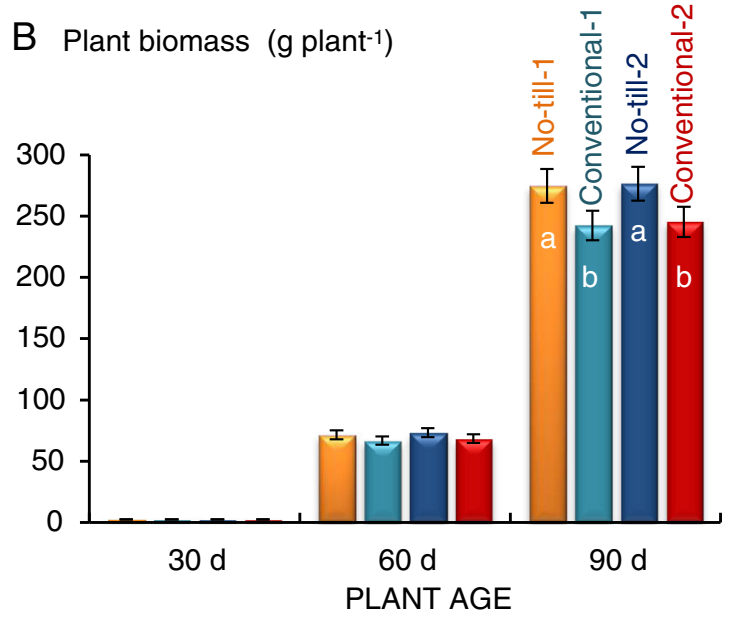

and 2013 (no-till-2 site and conventional-2 site). "No-till site" represents the average shoot length of two crop seasons (no-till-1 and no-till-2). Different field data are separated by line or bar colors. The values are the average of 20 plants. Significantly different values are indicated by different letters at $p$ value lower than $1 \%$ according to Tukey's HSD test

slightly higher on roots from the no-till site than on roots from the conventional sites. No-till practice appears to build up specific soil-borne pathogens (Sturz et al. 1997), and the yearly rotations with soybeans do not appear to address this concern. The degree of root infection was found to vary considerably among the replicated plots within the same fields. Interestingly, the level of root lesions did not always correlate with the grain yield loss or increase in any of the experimental

Number, percentage or weight (g)

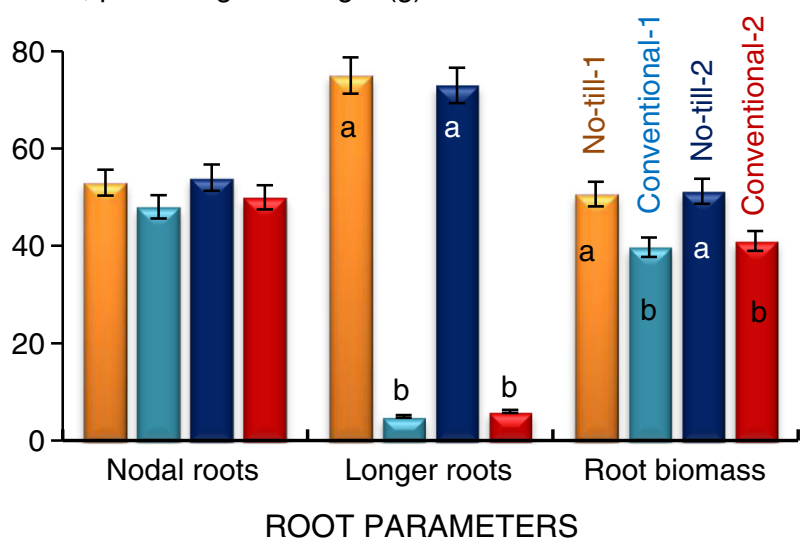

Fig. 3 Comparisons of root growth of maize grown in no-till strip row and conventional production fields. The data were obtained from no-till-1 in 2012, and no-till-2 in 2013 crop seasons. Conventional-1 and conventional- 2 sites represent the conventional maize fields in the year 2012 and 2013, respectively. Number of nodal roots per plant, percentage of plants having longer roots $(>35 \mathrm{~cm})$, and dry root biomass per plant $(\mathrm{g})$ from 20 replicate samples were analyzed at $90 \mathrm{~d}$ after planting. The bar colors represent data from different fields. Values separated by different letters within the same parameter are significantly different at $p$ value lower than $1 \%$ (longer roots) or $5 \%$ (root biomass) according to Tukey's HSD test 
Table 3 Comparisons of yield parameters, maize yield, production expenses, and net return

\begin{tabular}{|c|c|c|c|c|}
\hline Parameters/factors & No-till-1 & Conventional-1 & No-till-2 & Conventional-2 \\
\hline \multicolumn{5}{|l|}{ Ear parameter } \\
\hline Ear length $(\mathrm{cm})^{*}$ & $20.8 \mathrm{a}$ & $17.7 \mathrm{~b}$ & $20.6 \mathrm{a}$ & $19.4 \mathrm{a}$ \\
\hline Ear diameter $(\mathrm{cm})^{*}$ & $5.4 \mathrm{a}$ & $4.9 \mathrm{~b}$ & $5.5 \mathrm{a}$ & $4.7 \mathrm{~b}$ \\
\hline No. kernel $\operatorname{cob}^{-1} * *$ & $642 \mathrm{a}$ & $501 \mathrm{~b}$ & $645 \mathrm{a}$ & $490 \mathrm{~b}$ \\
\hline \multicolumn{5}{|l|}{ Grain yield } \\
\hline Each kernel weight $(\mathrm{g})^{*}$ & $0.35 \mathrm{a}$ & $0.30 \mathrm{~b}$ & $0.35 \mathrm{a}$ & $0.29 b$ \\
\hline Grain weight plant ${ }^{-1}(\mathrm{~g})^{* *}$ & $230 \mathrm{a}$ & $148 b$ & $228 \mathrm{a}$ & $141 b$ \\
\hline Total yield (ton ha $\left.{ }^{-1}\right)^{* *}$ & $18.3 \mathrm{a}$ & $10.7 \mathrm{~b}$ & $18.4 \mathrm{a}$ & $10.2 b$ \\
\hline \multicolumn{5}{|l|}{ Yield increases at no-till site } \\
\hline Plant $^{-1}(\%)$ & $55.4^{+}$ & & $61.7^{++}$ & \\
\hline Total ha ${ }^{-1}(\%)$ & $71.0^{+}$ & & $80.4^{++}$ & \\
\hline \multicolumn{5}{|c|}{ Factors reduced yield at conventional site } \\
\hline Late planting $(\%)$ & $7.0^{+}$ & & $7.0^{++}$ & \\
\hline Ear damages by the pest (\%) & $3.4^{+}$ & & $3.3^{++}$ & \\
\hline \multicolumn{5}{|c|}{ Factors increased yield at no-till site } \\
\hline Higher plant population (\%)* & $10.0^{+}$ & & $11.0^{++}$ & \\
\hline Larger ears $(\%)^{+++}$ & $50.6^{+}$ & & $59.1^{++}$ & \\
\hline \multicolumn{5}{|c|}{ Cost benefit per hectare $(C D N \$)$} \\
\hline Total expense & 1500 & 1500 & 1500 & 1500 \\
\hline Gross return & 3400 & 2000 & 3600 & 2000 \\
\hline Net income** & 1900 & 500 & 2100 & 500 \\
\hline
\end{tabular}

The components were compared between no-till-1 and conventional-1 fields in the 2012 season, and no-till- 2 and conventional-2 sites in 2013 . Values in one row with different letters are statistically different according to Tukey's HSD test at $p$ values less than $5 \%(*)$ or $1 \%(* *)$. Total yield $=$ yield plant ${ }^{-1}$ $\mathrm{X}$ no. plants ha ${ }^{-1} .^{+}$and ${ }^{++}$Differences between no-till-1 and conventional-1, and no-till-2 and conventional-2, respectively. ${ }^{++}$Larger ears $=$total yield increases at the no-till site - (factors that reduced yield at conventional site + increased plant population added to higher yield at no-till site). CDN $\$=$ Canadian dollar

plots. We are currently examining how to minimize the increased populations of root pathogens at the no-till site and perhaps generate yield increases above $20 \mathrm{tha}^{-1}$.

Both incidence and severity of ear diseases (head blight) were significantly higher in crops grown at the conventional-1 and 2 sites compared to those found at the no-till site (plower than $5 \%$ ), although none of the fields were sprayed with fungicides. At the conventional- 1 site, 5.2, 10.75, and $35 \%$ of ears were infected severely (20-30\% ear infection from the tip of the cob), moderately (10-19.9\% infection), or mildly (5-9.9 \% infection), respectively. In contrast, at the no-till-1 site, $0.5,0.75$, and $34 \%$ ears were found to be damaged severely, moderately, or mildly, respectively. The cumulative grain yield losses at no-till-1 and conventional-1 sites were estimated to be 1.8 and $5.2 \%$, respectively. Crop losses in no-till-2 and conventional-2 sites were estimated to be 1.7 and $5.0 \%$, respectively. Due to head blight disease, the grain yield losses at conventional- 1 and -2 sites were estimated to be 3.4 and $3.3 \%$ higher compared to those at no-till-1 and -2 sites, respectively ( $p$ lower than $5 \%$ ) (Table 3 ).
3.6 Grain yield, nutritional values in grains, cost of crop production, and net return

Measurements of all yield parameters of the no-till site were found to be significantly higher than that of the conventional site. The average cob sizes of no-till-1/2 sites (length, 20.8/ $20.6 \mathrm{~cm}$; diameter, $5.4 / 5.5 \mathrm{~cm}$ ) were significantly greater than similar measurements of cobs from the conventional-1/2 (length, 17.7/19.4 cm; diameter, 4.9/4.7 cm) ( $p$ lower than $5 \%$ ) (Table 3). Significantly higher numbers of kernels per cob were found with no-till-1/2 crops (642/645) than from the conventional-1/2 cobs (501/490) ( $p$ lower than $1 \%)$. Each notill-1/2 plant yielded $55.4 / 61.7 \%$ more grain on average compared to conventional-1/2, respectively ( $p$ lower than $1 \%$ ). Regardless of season, yield variation between replicate plots of no-till site was indistinguishable; for instance, no-till-2 site produced $21.22,22.54,21.63$, and $21.15 \mathrm{~kg}$ grains per 100 plants in plots $1,2,3$, and 4 , respectively. In contrast, variation of yields between replications was observed in the conventional sites. For example, 15.86 (plot 1), 15.11 (plot 2), 16.39 
(plot 3), and 18.88 (plot 4) $\mathrm{kg}$ grains per 100 plants were recorded at conventional-2 site. The final grain yields of notill-1, conventional-1, no-till-2, and conventional-2 sites were statistically different ( $p$ value lower than $1 \%$ ) and the productions were determined to be 18.3, 10.7, 18.4, and $10.2 \mathrm{t} \mathrm{ha}^{-1}$, respectively. The yields were comparable to the average yields harvested by the farmers, namely 18.1 (no-till-1), 10.5 (conventional-1), 18.0 (no-till-2), and 10.2 (conventional-2) $\mathrm{t} \mathrm{ha}^{-1}$. No-till-1 and -2 sites yielded 71.0 and $80.4 \%$ higher yields than conventional-1 and -2 sites, respectively ( $p$ lower than $1 \%$ ). Liu et al. (2014) recently reported yield increases and improvements of soil quality and fertility of cereal crops after 17 years of no-tillage management. Further, we determined the comparable quantities of nutritional values, namely starch (63-65\%), crude protein (9.1-9.3\%), total digestible nutrient (87-88 $\left.\mu \mathrm{g} \mathrm{g}^{-1}\right)$, and minerals in the kernels from no-till and conventional sites.

In this study, the yield contributing and reducing factors in no-till and conventional sites were determined. In conventional- $1 / 2$ sites, $7 \%$ yield loss was attributed to $7 \mathrm{~d}$ late planting, at $1 \%$ yield reduction per day (Bagg et al. 2009), and 3.4 and $3.3 \%$ losses were due to ear diseases in conventional- 1 and -2 sites, respectively (Table 3). Since no-till-1 and -2 sites had a plant density of 10 and $11 \%$ greater than conventional- 1 and 2 sites, they were estimated to yield 10 and $11 \%$ more grain conventional sites, respectively ( $p$ values lower than $5 \%$ ). Taken together, out of the $75 \%$ (average of no-till-1 and -2) yield increase at no-till sites, $21 \%$ (average of no-till-1 and -2) was due to sowing seeds at the optimal time, higher plant populations, and healthy ears/seeds, while $54 \%$ was due to bigger ears and more seeds. We are focusing our future studies on elucidating factors that contribute to the vigorous plant growth and formation of the larger ears found at the no-till site. The cost of production between no-till-1/2 and conventional-1/2 per hectare was the same, CDN $\$ 1500 \mathrm{ha}^{-1}$ (Table 3), since the extra tillage cost at the conventional sites was minimized by the additional seed cost of the no-till site. However, the average net revenue was CDN \$2000 ha ${ }^{-1}$ from no-till-1/2 site, and CDN $\$ 500 \mathrm{ha}^{-1}$ from the conventional-1/2 sites; therefore, the no-till sites were four times more profitable than the conventional sites ( $p$ less than $1 \%$ ).

Long-term no-tillage management has been demonstrated to be an effective and sustainable cereal production practice, generating $30 \%$ yield increases in wheat after 17 years of the practice (Liu et al. 2014). In Ontario, Canada, both no-tillage and conventional practices follow similar row/plant spacing and crop rotation and produced comparable maize yields in the years 2008-2012 (9.2 $\mathrm{t} \mathrm{ha}^{-1}$ ) (Bagg et al. 2009; Anonymous 2008-2012). We show here that changes in the agronomics of a no-tillage system which include leaving cropping rows undisturbed, integrating yearly crop rotation with an appropriate crop, growing plants exactly on the same rows every year, and maximizing plant population can improve the yields of maize by $75 \%$ in coarse texture soil located in southern Ontario, Canada. Fifty-four percent of the $75 \%$ yield increase is attributed to the larger ears, but the underlying mechanisms for producing bigger ears in the notill site crop has yet to be determined. We hypothesize that the enhanced plant growth and protection of ears from pests are due to the activity of soil and/or endophytic microbial communities (de Matos Nogueira et al. 2001), and we will present data elsewhere showing that the microorganism communities and their functions in soil and inside plant tissues at the two locations are vastly different. It is very likely that leaving the soil undisturbed along with repeated planting of particular crops enhances the evolution of microbial communities. This would allow for the establishment of a critical biomass of beneficial agents that can then colonize different plant organs (Peters et al. 2003; Chi et al. 2005; Kabir 2005). The reduced disease on the ears of no-till site maize could be due to microbial populations resident within the plant tissues and/or via induction of systemic plant resistance by the root-associated microorganisms (Pozo and Azcon-Aguilar 2007). There are other factors that could be implicated to the yield increases at the no-till site such as improvements in soil texture, soil quality, fertility, and yearly rotation of maize with a legume (Malhi et al. 2006; Riedell et al. 2009; Liu et al. 2014). It takes some years to establish such a highly productive ecosystem for maize (Rhoton 2000), and there are added costs associated with adapting farming equipment. However, over time, the benefits are enormous in terms of net return, sustainability, biodiversity, and environment impact.

\section{Conclusion}

This study demonstrated that it is possible to develop growing conditions for maize that generate significantly higher grain yields. Edgerton (2009) indicates that increases in maize yield will be derived primarily from introductions of novel genetic traits and will raise average maize yields of from 10 to $20 \mathrm{t} \mathrm{ha}^{-1}$ by 2030 . In his predictions, only $1 \mathrm{t} \mathrm{ha}^{-1}$ of additional increase will come from changes in agronomics over the next 15 years. We clearly show in this study that maize hybrids currently available can already produce $20 \mathrm{t} \mathrm{ha}^{-1}$, but do so only on soil where agronomic practices has been dramatically altered from practices currently used in North America. Our results provide very clear data that the yield potential of current maize varieties is not being realized. We hypothesize that under optimal production technologies, current maize varieties will yield over $30 \mathrm{t} \mathrm{ha}^{-1}$. We need a major change in attitude toward agronomic technology to achieve this. Current efforts aimed at changing the amounts of chemical inputs and their placement are likely to have minimal benefits to yield. However, focusing on creating agroecosystems and productive soils, as illustrated in this study, can provide the way 
forward for major breakthroughs in crop productivity. It is highly possible that by further tweaking this system, we can raise production to $25 \mathrm{t} \mathrm{ha}^{-1}$ in the next 5 years without having to pour enormous amounts of resources into creating more new hybrids. There is a need, however, to demonstrate that this technology will have equal benefits at other sites and whether the magnitude of yield responses will be of similar levels. If this production system can be reproduced, growers will find the technology less costly and more sustainable economically and environmentally.

Acknowledgements We acknowledge the assistance of Mr. Clarence Hessels for allowing us to perform this research on his farms. We are extremely thankful to the Grain Farmers of Ontario and Agriculture and Agri-Food Canada through the Canadian Agricultural Adaptation Program for their financial support to this project. We appreciate the advice and contributions of Mr. Greg Patterson, and the work Claire Jouan, Dave Rodriguez, Atheer Zarir, Lucas Albano, Jonathan Mahoney, and Christopher Chiasson did to collect samples and data. We would also like to thank Joshua Isaacson for his assistance proofreading and editing the manuscript and the A\&L Canada Laboratories Inc. staff for their help with this project.

\section{References}

Anonymous (2001) Agronomy handbook: A\&L Laboratories-Soil and Plant Analysis. A\&L Canada Laboratories Inc. http://www. alcanada.com/index_htm_files/Soil_Analysis_Guide.pdf. Accessed 20 May 2014

Anonymous (2008-2012) Provincial field crop production and prices estimates. Ontario Ministry of Agriculture and Food. http://www. omafra.gov.on.ca/english/stats/crops/index.html. Accessed 20 May 2014

Bagg J et al (2009) Agronomy guide for field crop: Ministry of Agriculture, Food and Rural Affairs. OMAFRA web. http://www. omafra.gov.on.ca/english/crops/pub811/p811toc.pdf. 811: 1-360. Accessed 25 May 2014

Barraclough PB, Weir AH (1988) Effects of a compacted subsoil layer on root and shoot growth, water use and nutrient uptake of winter wheat. J Agric Sci 110:207-216. doi:10.1017/S0021859600081235

Cakmak I, Hengeler C, Marschner H (1994) Partitioning of shoot and root dry matter and carbohydrates in bean plants suffering from phosphorus, potassium and magnesium deficiency. J Exp Bot 45:1245-1250. doi: $10.1093 / \mathrm{jxb} / 45.9 .1245$

Chi F et al (2005) Ascending migration of endophytic Rhizobia, from roots to leaves, inside rice plants and assessment of benefits to rice growth physiology. Appl Environ Microbiol 71:7271-7278. doi:10. 1128/AEM.71.11.7271-7278.2005

de Matos Nogueira et al (2001) Expression of sugarcane genes induced byinoculation with Gluconacetobacter diazotrophicus and Herbaspirillumrubrisubalbicans. Genet Mol Biol 24:199-206. doi:10.1590/S1415-47572001000100027

Deen W, Kataki PK (2003) Carbon sequestration in a long-term conventional versus conservationtillage experiment. Soil Tillage Res 74: 143-150. doi:10.1016/S0167-1987(03)00162-4

Edgerton MD (2009) Increasing crop productivity to meet global needs for feed, food, and fuel. Plant Physiol 149:7-13. doi:10.1104/pp. 108.130195

Franzluebbers AJ, Stuedemann JA (2014) Temporal dynamics of total and particulate organic carbon and nitrogen in cover crop grazed cropping systems. Soil Sci Soc Am J 78:1404-1413. doi:10.2136/ sssaj2014.01.0042

Gholizadeh A, Soom MAM, Aahim AA, Wayayok A (2011) Using soil plant analysis development chlorophyll meter for two growth stages to assess grain yield of Malaysian rice (Oryza sativa). Am J Agric Biol Sci 6:209-213. doi:10.3844/ajabssp.2011.209.213

Gozubenli H, Kilinc M, Sener O, Konuskan O (2004) Effects of single and twin row planting on yield and yield components in maize. Asian J Plant Sci 3:203-206. doi:10.3923/ajps.2004.203.206

Hobbs PR, Sayre K, Gupta R (2008) The role of conservation agriculture in sustainable agriculture. Phil Trans R Soc B 363:543-555. doi:10. 1098/rstb.2007.2169

Horwitz W (2003) Official methods of analysis of AOAC International, 17 th edn. Hopeland, Pennsylvania

Jones BJ (1999) Soil analysis-handbook of reference methods. Soil and Plant Analysis Council Inc., CRC Press LLC, Boca Raton, FL

Kabir Z (2005) Tillage or no tillage: impact on mycorrhizae. Can J Plant Sci 85:23-29. doi:10.4141/P03-160

Liu E et al (2014) Long-term effects of no tillage management practice on soil organic carbon and its fractionsin the northern China. Geoderma 213:379-384. doi:10.1016/j.geoderma.2013.08.021

Malhi SS, Lemke R, Wang ZH, Chhabra BS (2006) Tillage, nitrogen and crop residue effects on crop yield, nutrient uptake, soil quality, and greenhouse gas emissions. Soil Tillage Res 90:171-183. doi:10. 1016/j.still.2005.09.001

Mamolos AP, Kalburtji (2001) Significance of allelopathy in crop rotation. In: Kohli RK, Singh HP, Batish DR (eds) Allelopathy in agroecosystems. The Haworth Press Inc., New York, London, Oxford, pp 197-218

Martinez E, Fuentes JP, Pino V, Silva P, Acevedo E (2013) Chemical and biological properties as affected by no tillage and conventional tillage systems in an irrigated Haploxeroll of Central Chile. Soil Tillage Res 126:238-245. doi:10.1016/j.still.2012

Mills HA, Jones JB (1997) Plant analysis handbook II. A practical sampling, preparation, analysis, and interpretation guide. Micro- Macro Publishing, Ball Publishing, Batavia, IL, USA, p 422

Peters RD et al (2003) Developing disease-suppressive soils through crop rotation and tillage management practices. Soil Tillage Res 72:181192. doi:10.1016/S0167-1987(03)00087-4

Piva JT et al (2012) No till reduces global warming potential in a subtropical Ferralsol. Plant Soil 361:359-373. doi:10.1007/s11104012-1244-1

Pozo MJ, Azcon-Aguilar C (2007) Unraveling mycorrhiza-induced resistance. Curr Opin Plant Biol 10:393-398. doi:10.1016/j.pbi.2007.05. 004

Rhoton FE (2000) Influence of time on soil response to no till practices. Soil Sci Soc Am J 64:700-709. doi:10.2136/sssaj2000.642700x

Rice EW, Baird RB, Eaton AD, Clesceri LS (2012) Standard methods for the examination of water and wastewater, 22nd edn. Am Pub $\mathrm{H}$ Assoc, Am W W Assoc and W Envir Fed, New York

Riedell WE et al (2009) Crop rotation and nitrogen input effects on soil fertility, maize mineral nutrition, yield and seed composition. Agron J 101:870-879. doi:10.2134/agronj2008.0186x

Ryan RP, Germaine K, Franks A, Ryan DJ, Dowling DN (2008) Bacterial endophytes: recent developmentsand applications. FEMS Microbiol Lett 278:1-9. doi:10.1111/j.1574-6968. 2007.00918.x

Savci S (2012) An Agricultural Pollutant: Chemical Fertilizer. Int J Environ Sci Dev 3:No. 1. doi:10.7763/IJESD.2012.V3.191

Sturz AV, Carter MR, Johnston HW (1997) A review of plant disease, pathogen interactions and microbial antagonism under conservation tillage in temperate humid agriculture. Soil Tillage Res 41:169-189. doi:10.1016/S0167-1987(96)01095-1 